\title{
In the Shadow of Mnemosyne: The Poetics of Debt in Fiction and Testimony
}

\author{
KUJTIM RRAHMANI
}

\begin{abstract}
This essay aims to thematize the poetic and cultural-historical image of debt, embodied as memorial discourse in both fictional and nonfictional literature. The poetics of debt are forged within the melting pot of mythic and historical images, political and cultural aspects, and poetic and testimonial temporalities - but always sheltered in the shadow of Mnemosyne. Thus, memory remains a permanent umbrella for the different faces of debt. Debt is interrogated within the arc of authors Danilo Kiš and Zef Pllumi, two leading literary and cultural personalities in $20^{\text {th }}$-century south-eastern Europe. Their views provide a geopoetic and cultural background for a theoretical discussion of literary and cultural facets of debt. It is argued that because debt entails memory, obligation, and care for others, it is a distinguishing mark of the human psyche. The theorizing prelude will be followed by literary and confessional pieces of authors but, in the end, a theorizing observation on the subject will take place.
\end{abstract}

Keywords: memory; debt; poetics; testimony; fiction; culture

\section{Prelude}

Live to pay off debt.

Does Odysseus's return to Ithaca, after years of adventure and mourning, mean that he had finally paid back his due? If so, is the lesson for us that love and debt cohabit the psyche within mnemonic spaces?

It is a common human experience to grow up falling into debt and then living to repay it. Where does human debt come from? It seems that this question is experiencing a new horizon of thinking about the fiction of life and life of fiction, addressing different aspects of human morality and imagination. The debt is very likely to be an omnipresent phenomenon within the aesthetics of redemption. This is why hermeneutics of debt is back again, taking off the clerical clothing.

As spirits, daughters, and shadows of Mnemosyne and Zeus, the poets initiated their creative acts prompted by Muses. They discovered the debt sensitivity. Yet literature would not be possible without the ordinary recollection of things, events, people, images, and ideas. One believes that 
memory manipulates fiction and vice versa - their interplay goes on perpetually, either intentionally or spontaneously.

Throughout south-eastern Europe, at least during the last centuries, there has been a strong relationship between the individual and the mentality of debt. The reasons are complex, but no doubt relate in large part to ethnicity and national interests as psychological and social hyperimaginaries. In any case, debt has become not only the abstract conceptual throne of morality but has also activated a whole register of semantics within social, cultural, and literary discourses. From semantic radiance within language registers, debt has reached many nonverbal spaces of meaning. The metaphorical reach of the word debt has encompassed literal meanings by turning figurative semantics into tangible social language arrangements.

Obviously, the forms of memory and debt generated in south-eastern and central Europe were shaped by clashing mappings advanced by ideological regimes and nations as commanders of "collective identity" (Todorova 2004: 9). "The literary and artistic production in these areas involved a negotiation of tensions between nationalism and regionalism, metropolitan influences and local patriotism" (Cornis-Pope and Neubauer 2004: 5), forging moral and national interacting agendas in creating history and memory as a resulting vector of historical events. All these dramas have generated a sense of debt as an emotional and moral category.

In the second half of the 20th century, south-eastern Europe recognized both the semi-poetic, cultural, and ideological faces of debt embodied in oral and written discourses. Yugoslavia and Albania - despite their being from the same socialist camp - have had many differences with respect to the relationships between art and ideology. Two paradigms of the fictional and cultural/testimonial world of debt repay deeper investigation.

Socialist Yugoslavia after 1948 - the date of the political split with the Soviet Union - enjoyed greater artistic freedom than did the Soviet Union (many scenes from Solzhenitsyn's The Gulag Archipelago and the samizdat censored version of Bulgakov's The Master and Margarita perfectly illustrate the meaning of artistic freedom in the Soviet Union). This was especially the case after the Third Congress of the Writers' Union in 1952 in Ljubljana, when the rebellious Marxist thinker Miroslav Krleža (often associated with Tito; Čengić and Krleža 1985) called for more freedom and artistic space for artists and writers. Krleža's leftist views and partisanship for littérature engagée provided a license for the entire artistic world in Yugoslavia, much beyond the orthodoxy of Stalinist doctrine in the arts. 
At the beginning of the 1970s, a stormy clash between literary and cultural circles under the existing political realm intensified. Initially, the polemics concerned literary topics, but they soon escalated into the domain of national and human rights. Solidarity was established with other regional movements, such as the Czechoslovak Charter 77 manifesto, and had an impact in all parts of the state. Gradually, gingerly, ideological debts transcended into literary structures.

Albania, meanwhile, reflected the other face of the coin. From 1945 to 1990, the nation-building policy of arts and literature was activated within the ideological doctrine of Enver Hoxha's regime. Debt to the nation's honor was appropriated as a structural feature of literary and non-literary writings alike. This overwhelmed Albanian national literature, implicating it into new national political-military arrangements. This literature was initially presented as the supreme debt for the sake of national honor and duties.

The historical (and current) use of the psychology of debt seems to be an example of manipulating poetic debt in the favor of ideological debt. Nevertheless, the historical life-debt to remember and to tell remains always understandable after grand narratives in life.

This brings us to the very heart of an astonishing phenomenon: the human being, on the one hand, who detests being in debt, insists on paying it; and, on the other hand, the same human being takes debt pleasure as an embodiment of poetic and non-poetic relationships with the other.

Perhaps we can better understand the paradox of debt by turning to literature.

\section{Debt Viewed from the Deathbed}

The Debt is a short story by Danilo Kiš (1935-1989) from his posthumously published collection Lauta i ožiljci (The Lute and the Scars, 1994). Kiš is one of the most distinguished but also vexed literary figures in the former Yugoslavia.

The hero of The Debt, an old man, is in hospital, dying:

There was a whole life behind him, neither better nor worse than others'; he loved, suffered, travelled, wrote.

(Kiš 1994: 82; my translation)

But on his deathbed, when he was trying to tally up the balance sheet of his life, he felt anguished: 
RRAHMANI

And then, suddenly, as a powerful shock, a thought drove through his heart: he had not settled his debts. Not spiritual but terrestrial, material ones.

(Kiš 1994: 84)

In fact, the old man's debts were spiritual, even though the author uses a symbolic layer of material debt. (The discourse of physics becomes a stepping-stone toward metaphysics and nostalgia.) Now, while the life-giving fluid flows into his veins, he recalls his debts to everyone by leaving a testament of repayment. The liquid that transfuses time into his veins becomes a chronology of the events of his life; the chronos of memory becomes kairos, the chosen time. Chronological enumeration brings the old man's memory into the poetic shadow of Mnemosyne:

To Ivan Matkovšek, Wachtmeister, who opened my eyes to landscapes, just like a soldier learns from maps to read the area, two crowns.

To Ajkuna Hreljić, who was first to grab my hand and to help me cross the bridge, two crowns.

To Ani Matkovšek, who taught me the speech of flowers and plants, two crowns.

(Kiš 1994: 84-5)

But the old man's debt is also collective and cultural, even though poetically divided into singularities. Feeling indebted to individuals, he feels indebted to them also as a community. Being in debt here means also living with nostalgia while "the ethics of reflective longing recognises the cultural memory of another person as well as his or her human singularity or vulnerability" (Boym 337). He simply imagines the great family to which he is indebted and tries to donate a few crowns to each of its members. Finally, his nostalgia-and-love becomes debt and vice versa.

Kišs old man represents the human archetype that turns memories into debt, embodied both as a beautiful poetic experience and a moral poetics. One may imagine that some philosophy of memory always lies within the moral boundaries the person lives within. At the same time, these moral determining sources tend to be reconfigured into fictional testimonies and nostalgic poetic reality. It appears that paying one's debts is key to human salvation. This is why falling into debt has its own ugly and luminous faces in moral and ethical terms. The morality and ethics of debt often cohabit throughout their poetic and political interplay. Debt affirms the beauty of the ephemera as a reminder of the eternal.

Experiencing the debt, like the hero of The Debt, matters greatly in the cosmology of memory, time and space. Being in debt means, even fictionally, forging a memory. At the same time, to feel in debt means to recollect events 
that forge memory, a kind of memory habitude, which, at first glance, sounds mechanical, but, when repeated, urges new experiences along with a sentiment of debt. This sentiment has almost nothing in common with memorization or recollection by heart, like a recital. Rather, it interiorizes external events, gestures, and discourses. The authorial enumerative style of approaching the trésor of memories is meaningful too.

Where could the sentiment of being in debt be situated within the realm of ésprit-cerveau interplaying relations? In the story, the old man finds himself with a fundamental, ultimate debt to memory: he acknowledges that debt is what allows him to stay in touch with the world, humans, animals, and nature. In this vein, memory moves toward an ultimate interpretation, while the sentiment of debt and its imaginary strives for standards in support of this interpretation. Moreover, debt becomes a moral canon that takes part in building different memorial loci, images, and reminiscences that energize the creation of a real and fictional psychological map. The debt images and events from The Debt help to build a map of the cloth of memory; this cloth entails a sentimental recollection of roots of morality and nostalgia.

At the end of The Debt, Charon's boat embodies the passing of time on the other side. This way, the memory of the past will transcend the memory of the predicted, holy pass down the river to Hades. Charon, the ferryman of Hades, is waiting for his money for bringing the dead people on the shore of the ironically named promised land. There is always someone who pays for his own and others' memories; even for memories of the promised, dreamed, and desired loci on the other shore. The episodic memories listed one by one, as debts, by recalling past emotions, turn them into current life emotions characterized by profound nostalgia and melancholy. They serve as an intensification of final debt and event. Charon's request to be paid for taking the old man to the other shore recalls the Mesopotamian Epic of Gilgamesh when Ur-shanabi, the boatman, took Gilgamesh, the king, by boat toward the other shore (Dalley 2000: 102-20).

For the old man, to remember is to experience feelings, to feel is to believe, and to believe is to know and love at the same time: to find peace. Simply naming the persons leads to this path. "The idea that the essence of a person is referred to and expressed by a personal name gives the name a particular role in memory" (Margalit 2004:23) and a quite particular role in the story as well. The mentioned names - as events - make monuments in literature, forging dramatic space in memory and an unlimited space of the idea of debt. Memory, through the poetics of enumeration, serves perfectly as this imaginary state of morality transcending literary morality by showing caring emotions while paying debts. 
RRAHMANI

By forging poetic texture, genre, and sensibility, the old man's enumerative drama of debt always flashes back to cultural and historical scenes built within the fictional imaginary. I turn now to scenes illustrating historical recall, which entails an interiorized poetic discourse and sensitivity.

\section{Debt as a Mission}

In the Albanian Kanun (Customary Code/Canon), as in some primitive cultures, there exists the blood debt, which might be culturally translated into a culture of debt as a returning of things, emotions, and vengeance as a kind of (honor) debt return, as well. Debt recognizes the borrowing policy of relationships. Blood debt has been seen as a Procrustean bed for Albanian culture but this is just one dimension of the debt culture, from Homer and Aeschylus to Dante, Shakespeare, Dostoyevsky, Grass.

For half a century (1944-1990), Albanian literature was flooded by ideological doctrines. The return to the poetics of the personal, during the 1990s, has produced semi-literary forms such as biography, autobiography, and memoirs, parallel to pure literary forms such as novels, stories, and poems. Being encountered with such genres, and beyond its initial horizons, autobiography melded testimony and literature into one psychological entity.

Within this literature, "the disorienting sense of cultural discontinuity" (Lowney 2006: 7) has been intensified. Discontinuity was manifested as a traumatic confession of the past, and feeling lost and trapped within the new political, social, and economic regimes and their influences on mass psychology and cultural memory. The depressive view of the world interiorized the past, turning it into traumas, which would be exposed artistically in literature and the other beaux arts.

Obviously, the concept of trauma - parallel to the concept of memory - has evolved in relation to literary studies (Kurtz 2018). Its development accelerated in the 1990s, parallel to the split with communism in south-eastern Europe, perhaps with Pierre Nora's oeuvre in the 1980s. Although the "literature of trauma is defined by the identity of its author" (Tal 1996: 17), "the thinking of the archive is, in this sense, not only a thinking of memory but a thinking of history" (Caruth 2014: 18). Traumatic perception and writing became allies of historical perception and merged with it into testimonial discourse.

The grieving tone of poetic imaginary has affected almost every Albanian writer. In brief, in spite of the fact that fiction and poetry are not designed to offer factual testimony, "they may tell us something about what it is to be traumatised" (Hunt 2010: 171). In addition, during the last several decades, 
after 1990, the sensitivity of the victim has been converted into a heroic culture in the Albanian fictional mind. Memory of the victim has produced a literature of trauma as a kind of collective and even personal debt, turning the literary mind into an intentional selecting mechanism of testimonials and imagined loci in history and life. Traumatic memories are always there and literary, poetic situations afford a perfect space for such traumatic palimpsests.

Is Albanian literature a kind of literature of candles - a dolor-evoking or aide-mémoire that gives access, fictionally, to obscure eras? Is debt necessarily associated with candles and graves? Obviously, candles always call up traumas by excluding current sentiments of joy. But the poetics of debt is much more deeply rooted than having merely a commemorative status.

The memorial scent of this literature of candles sometimes overshadows the poetic status of the Albanian fiction today because, as mimetic theories insist, "traumatic events cannot be absorbed or represented, and as such the victim is fated to repeat or act it out in various ways" (Bell 2006: 9). The sentiment of debt associated broadly with memory for the other ones, yesterday and today, has been reinstated as an emotive instrument against itself, taking an almost secular religious form. As for curiosity, such poetic debt takes different shapes from the one in Kiš's story. Rather than his personal indebtedness, it will take the shape of collective common debt by being reframed as a historical mission that can bring peace of mind through catharsis.

One of the most brilliant examples of such a phenomenon in Albanian letters is the imaginary debt expressed as testimony in the autobiography of Zef Pllumi. Father Pllumi (1924-2007) first published Rrno vetëm për me tregue in 2001 (revised 2006; Schank's English translation, Live to Tell, appeared in 2008). Live to Tell is a moral and physical witness to a life under communist dictatorship for half a century. Pllumi has coalesced his dolorous memories into documentary-literary form. Even though the expression documentary-literary sounds like an oxymoron, in this case there is a semantic equilibrium between two words and domains.

An Albanian Franciscan priest, Pllumi spent twenty-six years in prison where he memorized dates, events, voices, and ideas - monstrous crimes and punishments from Hoxha's communist regime. After he was released in 1989, Pllumi undertook to document the half-century under irons in Albania: a testimony of life experienced from prison.

Carrying within himself a national purpose, he entirely fulfills the conditions of being a moral witness, because a moral witness "is one who experiences suffering - one who is not just an observer but also a sufferer" (Margalit 2004: 150). Pllumi's account of his experiences pays tribute to 
great literary and public actors of the half-century under Hoxha's dictatorship. His memorized history and testimony are retold in a cultural-literary autobiographical style, just as the Gulag actors have told their stories: supreme authors who splice the personal and the national together into scenes of human poetics and politics.

Bearing in mind the sensitive status of memory for traumatic conditions, one cannot avoid the question, "How do we recognize a memory and not confuse it with a fiction?" (Ender 2008: 91). Despite the fact that the genre of the book is announced as autobiography, there are no clear boundaries between the historical and the poetic. The aesthetics of the text are indebted to national history, which is eagerly forgotten within the ruins of memory. But, "because so much of the literary material is overtly and emphatically autobiographical, it can profitably be explored as a series of case histories of a variety of operations of human memory" (Nalbantian 2003: 3). In short, Pllumi's account is discursively and psychologically far more complex than typical autobiography.

Unlike the beauty of the ephemera in debt, as in Kiš's short story, here we have the tangible, historical touch of debt - the moral beauty of debt is embodied as memory and as mission.

Pllumi's intention is to find within the genre of autobiography the true language of testimony. He declines to tell some of the most extreme incidents of his life under tyranny because nobody would believe that, as he used to reaffirm. Instead, he achieves an unusual balance between documentary and fictional writing, retaining some distance to real events in order to remain plausible. Thus, the author's intention not to be fictional - in the sense of historical untruthfulness - provides, paradoxically, a fictional aura. He has simply written an autobiography, a memory, a kind of chronicle that spontaneously transcended into literature.

The first impression is that the entire oeuvre speaks as one - testimony and literature at the same time. In fact, "The permanent threat of mélange recollection and imagination resulting by turning the memory into image, hurts the ambition for loyalty as an embodiment of the veritative function of memory" (Ricoeur 2000: 7). Nevertheless, the fact that this can happen does not mean that the nature of memory is denaturalized. This is a debt toward the poetics of human thinking turned in favor of memory honesty. Memory continues to be a confirmation of what we are and what we want to be. Even so, as Ricoeur (2000) says, "We do not have anything better than memory in order to ensure that something has happened before we have founded our souvenirs" (7). 
Pllumi exemplifies the author who has a debt to testify to the world what he has seen, heard, and suffered. In time, the debt becomes a mission. For a clergyman, a special debt can always convey a mission. The following excerpt depicts the drama in which this mission emerged:

The Superior Father Marin Sirdari called me to his room just for a word.

"Look at me, boy," he said, "I appreciate your single-mindedness, but don't boil over - enough is enough. You know what I am saying? You came here at the hardest time that Catholicism has ever had, us in particular. Go back to your village, where you belong, get out of sight; don't talk to anyone; trust nobody, not even yourself. We need you alive, not dead.

"If push comes to shove, we, the elders, have finished our journey; it's you, the youth, who must live. Our Lord is great. To his splendor we praise the creation of death; otherwise, people would experience tyranny's slavery forever. One day they will die, and you must live just to tell the story. If there is nothing else you can do, live to tell. Do you know what I mean? Everything is over; we are done, and your days will go by as well, and we all fall down just like nothing if there is no one to tell the story. Only he who is left standing can tell the tale! ... Get it? Well, Zef, in the time being, I am your superior, and I am giving you an order: Go, live! Just to tell the tale."

(Pllumi, 2006: 253; my translation)

Thus, the hero clergyman embarked on the mission to remember and to tell the entire story. As a missionary who "forgives but doesn't forget," he embodied his testimony in a mission to human and national memory.

Today Live to Tell is experiencing acceptance as a literary monument to lives ruined under the repressive regime in Albania, 1945-90. But the book is more than a horrific account of the Albanian version of Stalinism. It engages the cosmology of Albanian traditional values and endeavors by offering tangible evidence of relationships between history, political ideas, and literary culture. History and poetics coexist, and their cross-historical and cross-poetic vectors are revealed. Although it may be supposed that history is intentional - "to tell and to go" whereas literature is merely supplemental, the text displays the poetic dimension powerfully, showing fiction and documentary to be a single, seamless entity.

Through the historical and poetic layers of the self-confession, the book sheds light on what it means to be human. The narrative tells the story and builds the meta-story, from first interrogation and incarceration through many camps and jails - a mosaic of the world under tyranny. Memory and the chronicle come together as a thrilling cinematographic memory of Albanian culture and politics.

Through it all, Pllumi remains the priest who came to experience and to have a memorable Erlebnis, to taste life under irons, to offer testimony, to forge 
RRAHMANI

a documentary-literary testimony, and then - as in fairy tales - to go away, to vanish.

He, paid, finally, the debt he had promised to his superior.

Thus, we see that, paradoxically, Kiš, a secular writer, was concerned with paying his poetic, terrestrial, and divine debts, whereas Pllumi, a clergyman, framed his debt mainly as terrestrial, in order to tell the others about the hell he went through.

According to Margalit (2004), "The human project of memory, i.e., commemoration, is basically a religious project to secure some form of immortality" (25). It is therefore fitting that it is the priest Pllumi who underscores the national weight of the project by contextualizing its religious premises within the imaginary of the national. He refuses to be indifferent: the banality of indifference would be as unacceptable as the regime's banality of evil. Thus memory is an obligation that "stems from the effort of radical evil forces to undermine morality itself by, among other means, rewriting the past and controlling collective memory” (Margalit 2004: 83).

Kišs The Debt and Pllumi's Live to Tell exemplify poetic-cultural regimes that interact with and motivate each other; they offer raw material from emotional and intellectual sources alike. However, "manipulation" here remains an original poetic sensitivity transcended aesthetically, on the way. The individual imaginary of Kiš and the collective imaginary of Pllumi both serve to nurture debt-memory discourse.

\section{On Memory-Debt Poetic Interplay: A Theoretical Offshoot}

The skills of ars memoria remain a magic or occult art characterized by the effort to bring memory to life - everyday life - not only for the sake of monumental art but for the sake of the direct artistic relationship with life as well.

Memory preserves a close emotional distance to life by envisaging images and dramas as representations. Previously experienced images and events invade our life now by mixing referential relations between memory and literature where mnemonic art plays a crucial role (Renate 1990). Thus, the philosophy of memory is largely occupied with elucidating the relational interplay between different agencies of mind and emotions, concepts, and percepts.

First of all, it seems like the ultimate voice of memory starts from basic designation and representation of images and deeds toward many complex and sublime interpretations. Consequently, very often, mnemonic discourse takes attributes of an argumentative, persuasive, rational, or intuitive discourse. But, 
in fact, memory seems to survive through a discourse that is always emotionally motivated and intellectually employed, being turned into papyrus for new palimpsests. It is sanguine; poetic origins might hurt documentary memory to the extent that the very identity of memory becomes mutilated, thus turning memory into an absent, incidental, and humiliating agency of human character. It therefore makes sense to insist that "meaningful life is the life of reflective memory, not the life of blind experiences" (Margalit 2004: 134).

Fortunately, memory has its own transitive biological sensors keen to fictional entities. Indeed, memory is arguably foundational for the entire scope of subtle relations between human beings. Among many others, the imaginary of debt depends on memory.

Just as a material debt implies moral/metaphysical debt, an emotional relation implies poetic debt. But poetic debt is regenerated and reconfigured by passing through the transcendence of historical time (chronos) into poetic/ chosen time (kairos). Debt collects and re-collects subjects, images, things, words, and events. Supported by this temporal conceptual framework, debt transcends narrow social constructions, becoming a permanent open locus and radiating source for new horizons of emotions and ideas. Debt recalls memory as a call of life experiences, though sometimes ends up as a mechanical ritual that preserves traces of an affective Erlebnis. At the same time, memory recalls debt, and hearing the voice of the call means feeling the voice of debt. Hence, debt perception and understanding become an irreversible foundational process for memory, forging in this way the poetics of the interplaying memory of debt.

The debt from the eponymous story by Kiš borrows memorial discourse to build its fictional philosophy. Antithetically, the testimonial discourse in Pllumi's Live to Tell borrows the concept of debt to build the moral and cultural philosophy of personal and common history. Thus, in these two works we witness debt's journey from rhetoric to history and to metaphysics, with colorful and meaningful life illustrations, using "mobile and immobile memory spaces" (A. Assmann 1999: 114), within the personal or collective realm. The heroes of these works found a fine way to experience the journey toward redemption.

Any strategy of poetic memory becomes aware that "everyday life means schematization and routinization" (J. Assmann 1997: 85). Poetic memory steers clear of turning life's superficialities into debt relations. Real debt perception serves to recreate, as opposed to reproduce, the event's memory; poetic debt is an art that seeks to qualify memory "through a technique of impressing places and images on memory" (Yates 1966: xi) as ingredients of the artistic event. The indebted state of mind teaches us mnemo-technics by implicating our current status permanently within the past or within the future as prejudice or utopia. 
Usually, the past has an impact on our future - it depends on when we pay off the debt. When we do, we will be probably relieved from the memory identified with it, in spite of fact that poetic debt, by its very nature, is unpayable. The role of the debt imaginary as a turning point of reflexive memory comes to play at this very point. Debt dwells between today and yesterday, like memories; after all, "memories are not static representations of past events, but 'advancing stories" (Edric and Fuchs 2003: 12). Thus, the poetic imaginary goes back and forth, rises and falls, remaining an absolute space of possibilities. Within this space, the imaginary of debt actualizes an intense visual dramatization of debt, including its causes. Debt is forged as an unconditional call of the events with great agency to create a memory locus - a rich space of vivid memories and images. Thus, the debt imaginary has the power to help anyone generate appropriate loci like the old man from The Debt.

It follows that falling into debt has a bipolar movement: to pay a debt from the past, one borrows from the future, but then a new debt to the future appears. In this sense debt is always - everlastingly - with us. However, the unpayability of debt does not exclude the sentiment of happiness; indeed, poetics yearns for such a sentiment.

The culture of debt seems to be naturally attached to an individual and to a collective culture of memory. Recollecting, individually and collectively, has poetic implications that come into being to a greater or lesser extent depending on the emotional, intellectual, immanent, and transcendental embodied capacities. In sum, the culture of debt becomes a bedrock of human culture of redemption.

In modern times - in particular, from the time of Querelle des Anciens et des Modernes and The Battle of the Books - a perpetual conversion of mythical and religious faces of debt into secular values was initiated. It is exactly the timespace arch where old poetics, under pressure from new social and psychological circumstances, began to be reframed into new poetic-political relationships. The divine-terrestrial homeland of debt makes it able to cohabit with great moral codes throughout the many discourses rooted in myth and religion, poetics and politics.

The etymological echo of debt from the Latin debitum/debere - to be obliged, to have a duty (to pay something: mortgage, gratitude, religious sin or guilt, love) - rises much further in the moral and emotional imaginary, by forging the poetics of debt in a very large field of economic, intellectual, jurisdictional, moral, and emotional levels. Across this array, the give-and-take relationship generates the institution of debt. Being necessary both poetically and economically, debt becomes a moral necessity that goes far beyond the 
institution of money or its substitutes. Due to its transcendental materialimmaterial nature and capacities, ultimately no one can pay what is due.

On the other side, debt always remains a constitutional part of morality in the theology of sin, where the moral obligation transcends its economic - call it its mortgage sense - by displaying moral neutrality, like in brilliant verses of the poem Debt by Paul Laurence Dunbar: Slight was the thing I bought/ Small was the debt I thought/ Poor was the loan at best - / God! but the interest!

The moral neutrality of mortgage debt (compared to stealing, for example) means that "a relevant difference between borrowing something and stealing it is that in the former case whoever takes it gives it back" (Douglas 2016: xi). So, in the culture of debt, trust is essential. Moreover, "the need for continuing general trust in the whole institution of debt plays a key part in explaining why debts should ever generate obligations" (Douglas 2016: xiii). Debt, by generating trust and care, generates an ongoing cycle of obligation. Therefore, debt stands in sharp contrast to the absurd and other regimes of emotional emptiness.

The metaphysical and poetic desire to fall into debt has emotional consequences: we are moved beyond indifference toward memory and care for others. Caring for the other means engaging in a relationship that is at once poetic and social. It is a relationship beyond practical reasons, and it provides a ground, as well, for ritual feelings. To care is to enter into a relationship of indebtedness that embodies moral and ethical attitudes. If care should fail and the debt be unfulfilled, the normal consequence is shame.

Because they generate a cyclical, ongoing process of inputs and outputs, falling into and paying debt are fundamental for moral, cultural, and everyday life. When these generating structures take the forms of fiction and testimony, as in the cases discussed earlier, debt is transcended into ethical (both individual and communal) poetics. By feeling moral and ethical illusions and principles, debt phantasmata are inclined toward delivering imprisoned memory - sentenced to death. Accordingly, the poetics of debt includes it within an arc of interpretation as an emotional and psychological entity in the form of an instrument of enslavement and violence (Lazzarato 2015). By this principle, debt constitutes an action category implied within the motivational radius of heroes and their worldly deeds and moral imaginary.

In normal social terms, falling in debt means not only creating contract or relationship but also falling in love with the other - a person, idea, or thing - as one might always enjoy sharing emotions, care, and affection with someone/ something. The imaging power of the debt imaginary may distill events from embryonic memory and arch-situations into a fictional imaginary. At the same 
time, debt can deliver a perpetual remembering and evocative effect - without negating its imaginary effects - though it dwells more in moments than in long narratives. Poetically inclined debt perception owes much of its retrieval abilities to eikōn due to quite particular ties with phantasmata.

At some point, the fictional imaginary of debt always becomes a cultural imaginary, as a "complex lieu de mémoire with its very own forms and strategies of observation and writing from older memories and their diverse representations" (Eckstein 2006: ix). Interrogating these memory loci beyond engineered perspectives brings memory closer to the lens of a semiological telescope of memory focused on two main stars: lived experience/Erlebnis and fiction, which, from very great distances, melt into or alternate with each other.

Debt, through the memory of fiction and fiction of the memory, always brings us to the same desired, dreamed-of point: paying the debt by feeling the pain, paying the debt by enjoying the wine, and enjoying life by paying the debt-tax for vivid, dreadful, playful, and joyful living spaces.

To fall into debt, poetically, is to invest in wonderful emotions and experiences; to be in debt is therefore to live in the shadow of Mnemosyne. Beyond the field of debt lies the wasteland, as we see in Kiš's story and Pllumi's memoir. Wandering down the path of debt, it slowly dawns on us that debt is a gift. Thus, as astonishing as it may first sound, we can boldly affirm: Live to be in debt!

\author{
Kujtim Rrahmani \\ kujtim68@gmail.com \\ Instituti Albanologjik \\ Rr. Eqrem Cabej, pa nr. \\ 10000 Prishtinë \\ KOSOVA / KOSOVO
}

\title{
References
}

Assmann, A. 1999. Erinnerunsräume. München: Verlag C.H. Beck.

Assmann, J. 1997. Das kulturelle Gedächtnis. München: Verlag C.H. Beck.

Bell, D., ed. 2006. Memory, Trauma and World Politics. New York: Palgrave Macmillan. Boym, S. 2001. The Future of Nostalgia. New York: Basic Books.

Caldicott, E.; Fuchs, A., eds. 2003. Cultural Memory: Essays on European Literature and History. Bern: Peter Lang AG, European Academic Publishers.

Caruth, C. 2014. After the End: Psychoanalysis in the Ashes of History. - M. Nadal, M.

Calvo, eds., Trauma in Contemporary Literature: Narrative and Representation. New

York \& London: Routledge, 17-34. 
In the Shadow of Mnemosyne: The Poetics of Debt in Fiction and Testimony

Čengić, E.; Krleža, M. 1985. S'Krležom iz dana u dan: Trubač u pustinji duha (II). Zagreb: Globus.

Cornis-Pope, M.; Neubauer, J., eds. 2004. History of the Literary Cultures of East-Central Europe, II. Amsterdam: John Benjamins Publishing Company.

Dalley, S., ed. 2000. Myths from Mesopotamia: Creation, the Flood, Gilgamesh, and Others. New York: Oxford University Press.

Douglas, A. X. 2016. The Philosophy of Debt. New York: Routledge.Eckstein, Lars 2006. Re-Membering the Black Atlantic: On the Poetics and Politics of Literary Memory. Amsterdam \& New York: Rodopi.

Ender, E. 2008. Architexts of Memory: Literature, Science, and Autobiography. Ann Arbor: University of Michigan Press.

Hunt, N. C. 2010. Memory, War and Trauma. Cambridge: Cambridge University Press.

Kiš, D. 1994. Lauta i ožiljci. Beograd: BIGZ

Kurtz, J. J., ed. 2018. Trauma and Literature. New York: Cambridge University Press.

Lachmann, R. 1990. Gedächtnis und Literatur: Intertextualität in der russischen Moderne. Frankfurt am Main: Suhrkamp Verlag.

Lazzarato, M. 2015. Governing by Debt. Transl. J. D. Jordan. Los Angeles: Semiotext (e).

Lowney, J. 2006. Memory, and Literary Left: Modern American Poetry, 1935-1968. Iowa City: University of Iowa Press.

Margalit, A. 2004. The Ethics of Memory. Cambridge \& London: Harvard University Press.

Nalbantian, S. 2003. Memory in Literature: From Rousseau to Neuroscience. New York: Palgrave Macmillan.

Pllumi, Z. 2006. Rrno vetëm për me tregue. Tiranë: 55.

Pllumi, Z. 2008. Live to Tell. Transl. K. Schank. Bloomington: iUniverse.

Ricoeur, P. 2000. La mémoire, l'histoire, l'oublie. Paris: Éditions de Seuil.

Tal, K. 1996. Worlds of Hurt: Reading the Literatures of Trauma. New York: Cambridge University Press.

Todorova, M. 2004. Balkan Identities: Nation and Memory. New York: New York University Press.

Yates, F. A. 1966. The Art of Memory. London \& New York: Routledge. 